\title{
葉片浸漬法と散布法によるナミハダニの感受性検定の比較および 簡易なハダニ接種法の開発
}

\author{
國本佳範・今村剛士
}

\begin{abstract}
Yoshinori Kunimoto and Tsuyoshi Imamura:
A comparison between two susceptibility test methods, chemical spray and leaf dip, for two-spotted spider mite and development of a simple method for placing mites on a leaf disk
\end{abstract}

\begin{abstract}
We compared the mortality of mites between two susceptibility test methods, chemical spray and leaf dip, with bifenazate, emamectin and cyenopyrafen for the two-spotted spider mites on strawberry. When using bifenazate and cyenopyrafen, there was no difference in mortality of mites between the two methods. However, when using emamectin, the mortality by the leaf dip method was significantly lower than that by the spray method.

A new method of placing mites on the leaf of kidney beans without using a fine brush was developed. That is, a small strawberry leaf infested with mites was placed by an intact stem of kidney bean with one primary leaf for a day. Most mites on the strawberry leaf moved onto the kidney bean leaf by themselves. There after the kidney bean leaf with mites was dipped in the acaricides for five seconds. By using this placement method followed by the leaf dip method, the mortality was similar to that of normal placement method using a fine brush followed by the spray method.
\end{abstract}

\section{緒言}

ハダニ類は薬剤抵抗性が発達しやすいことが知られて おり（真梶，1970），奈良県でも複数の殺ダ二剂に対し てイチゴ等に寄生するナミハダニ黄緑型の感受性が低下 している（國本，2010）。このため，生産者への防除指 導は感受性検定の結果に基づいて行うことが望ましい。

ハダニ類の感受性検定法としては，ハダニ類を接種し たインゲン葉に殺ダニ剂を散布する方法（浜村, 1996） （以下，散布法）や，あらかじめ殺ダ二剂に浸漬した インゲン葉にハダニ類を接種する方法（望月, 1998), (http//www.irac-online.org/methods/panonychus-ulmitetranychus-species-adults/, 以下, 浸漬法）などが知られ ている。ただし, 浸漬法での供試殺ダニ剤は, ブロモプ ロピレート, サイヘキサチンあるいはミトコンドリア電 子伝達系 I 阻害剤などとされており，これらは現在の促 成イチゴ栽培では使用されていない。そこで, 促成栽培 イチゴの栽培現場で使用されている殺ダ二剂を対象に, 両検定法を比較したところ, 死亡率に違いが生じる薬剤 があることがわかったので報告する。
また，両検定法ではインゲン葉へのハダニの接種に小 筆が用いられる。ところが, この方法は作業に熟練が求 められるうえ, 長時間の細かい作業となるために作業者 の精神的疲労が大きい。そこで, 小筆を用いない八ダニ 接種法を開発したので併せて報告する。

なお，本研究は農林水産省委託プロジェクト「ゲ ノム情報等を活用した薬剂抵抗性管理技術の開発 (PRM2303)」で実施した。

\section{材料および方法 \\ 1. 両検定法の比較 \\ 供試したナミハダニ黄緑型は2015年 5 月 25 日に奈良県 桜井市東田, 2015年 6 月 4 日に高市郡明日香村平田の促 成栽培イチゴ施設（品種：アスカルビー）から採集し た。供試した殺ダニ剂はビフェナゼート水和剂(1000倍, 日産化学工業株式会社), エマメクチン安息香酸塩乳剂 (2000倍, シンジェンタジャパン株式会社)，シエノピラ フェン水和剂（2000倍, 日産化学工業株式会社）で, 対 照として水道水を用いた。各検定法は以下の手順で行った。}


散布法 : (1)リフディスクの作成 : 水で湿らせた濾紙 を敷いた $9 \mathrm{~cm}$ シャーレ上にインゲン初生葉（品種：長 鶉菜豆）を葉表を上にして置き，湿らせたペーパータオ ルで $3 \mathrm{~cm}$ 四方に囲った。(2)ハダニの導入 : リーフディ スクに小筆でナミハダニ黄緑型の䧳成虫を 20 頭程度導入 した。数時間放置後, 実体顕微鏡下で生存虫を計数し た。併せて，ハダニが吐出した系を除去した。(3)殺ダニ 剂散布 : 当センターでは回転式散布塔を所有していない ため，これに代わる簡易な散布法としてハダニを接種し たリーフディスクをターンテーブルに乗せ，エアブラシ (スプレーワーク HGトリガータイプ, 株式会社タミヤ) で供試殺ダ二剂を約 $2 \mathrm{mg} / \mathrm{cm}^{2}$ となるように散布した。

浸漬法 : (1)殺ダニ剂への浸漬 : 展開したインゲン初生 葉を供試殺ダニ剂に 5 秒間浸漬し, 風乾した。風乾後の インゲン葉を用いて散布法の(1) と同様の方法でリーフ ディスクを作成し，(2)と同様にハダニを導入した。

いずれの検定法も処理24時間後, 48時間後に実体顕微 鏡下でハダニの生死を判定した。脚の痤攣などの苦悶 虫は死亡とみなした。試験は 3 反復行い, Abbottの式 （Abbot，1925）により補正死亡率を算出した。

\section{2. 簡易なハダ二類接種法}

実験にはナミハダニ黄緑型の餌植物として幅広く利用 され，容易に栽培できることからインゲン（品種 : 長鶉 菜豆）を用いた。展開した初生葉を 1 枚残したインゲン 茎を, 水を入れた直径 $2.5 \mathrm{~cm}$, 高さ $10 \mathrm{~cm}$ のプラスチッ ク製容器に挿し，切り込みを入れたスポンジでインゲン 茥を挟むようにして容器の口部分に固定した。これを高 さ $10 \mathrm{~cm}$ の発泡スチロース製の箱に空けた穴に差し込ん だ（第 1 図）。あらかじめ寄生するナミハダ二黄緑型雌 成虫を計数したイチゴ小葉をインゲン茥元に接するよう に置き，24時間後にインゲン葉上のナミハダニ黄緑型雌

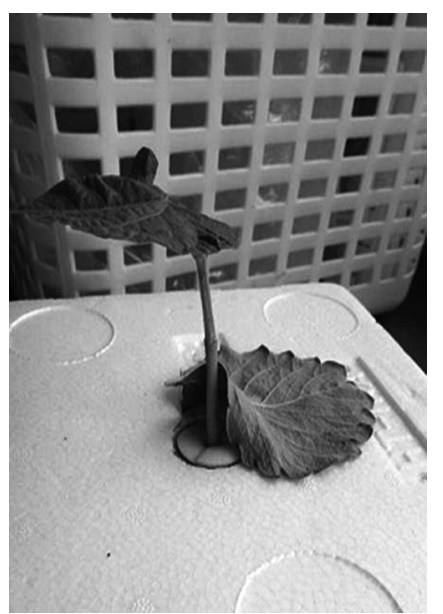

第 1 図＼cjkstart水挿しインゲンへのハダニ接種
成虫を計数した。また，1.で供試した桜井市東田の個 体群を上記の方法でインゲン葉に移動させた。これを 1 . で供試した殺ダニ剂に 5 秒間浸漬し，24時間後に実体顕 微鏡下で生死を確認し, 補正死亡率を算出した。

\section{結果}

1. 両検定法の比較

両検定法での48時間後の補正死亡率を第 2 困に示し た。ビフェナゼート水和剂では供試したいずれの個体群 においても，両検定法の補正死亡率は 100\%と高く，両 者間に差はなかった。一方, エマメクチン安息香酸塩乳 剂の浸漬法での補正死亡率はいずれの個体群でも低かっ たが，散布法では死亡する個体がかなり見られ，いずれ の個体群でも両検定法の間に有意差があった（Fisherの 直接確率検定, 危険率 1\%)。シエノピラフェン水和剂 ではいずれの個体群でも散布法でわずかに死亡する個体 があったが，両検定法ともに補正死亡率は低く，両者 間に有意差はなかった（Fisher の直接確率検定，危険率 $1 \%)$ 。

2. 簡易なハダ二類接種法

イチゴ小葉上のナミハダニ雌成虫数と 24 時間後にイン
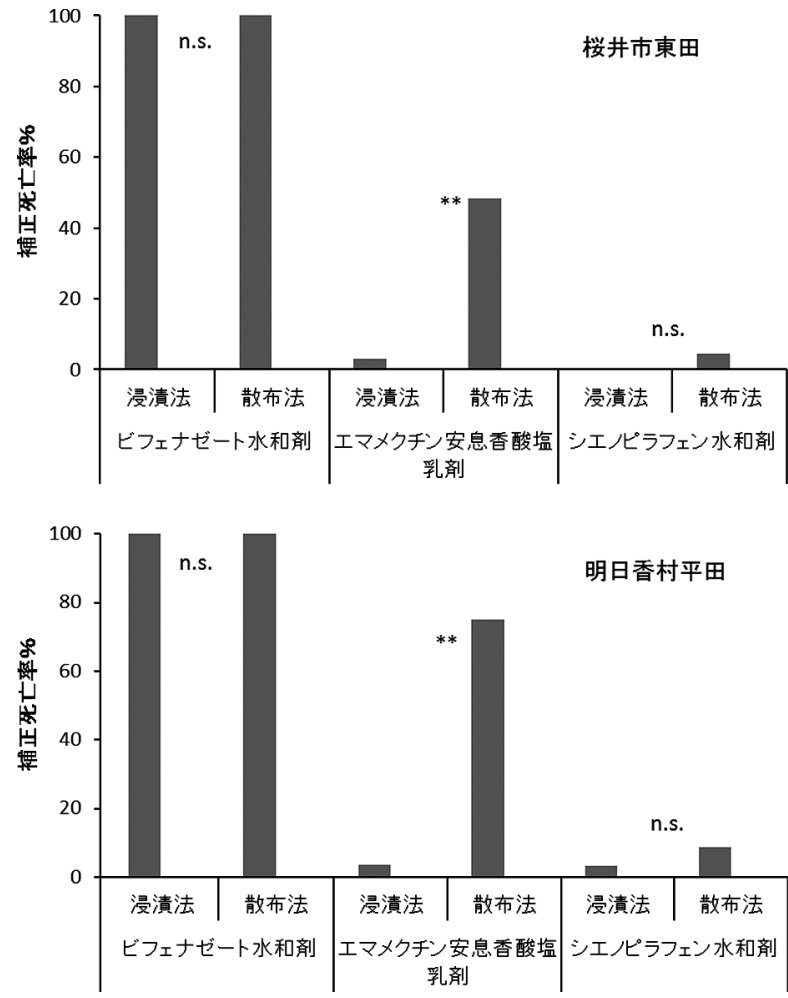

第2図 ナミハダニ黄緑型に対する各殺ダ二剤の浸漬法と散布 法での補正死亡率 n.s. は Fisherの直接確率検定で有意差がない, **は 1\% 危険率で有意差があることを示す。 


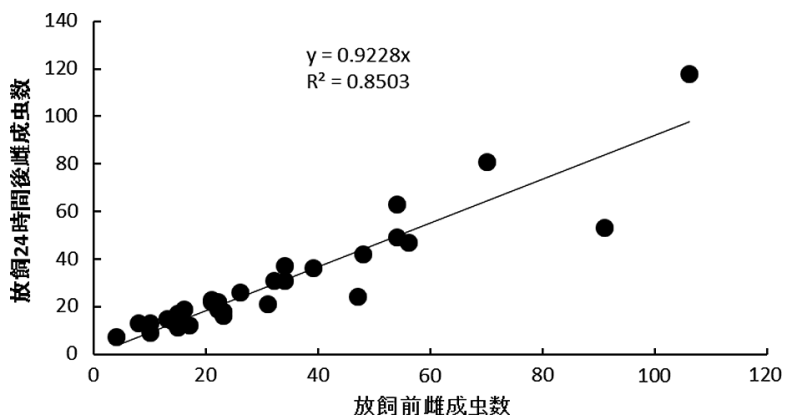

第 3 図 放飼前のイチゴ小葉上ナミハダニ雌成虫数と放飼24時 間後のインゲン葉上のナミハダニ雌成虫数の関係

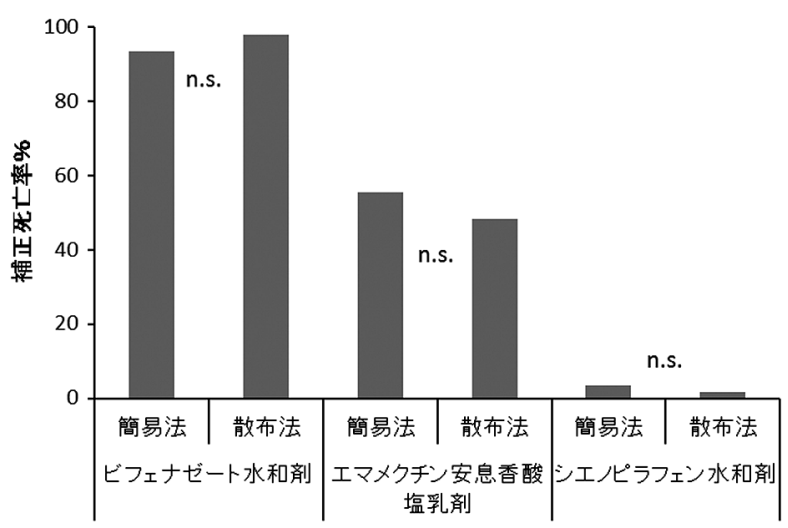

第4図 ナミハダニ黄緑型に対する簡易接種後の葉片浸漬と小 筆を用いた接種後の薬液散布での各殺ダ二剂での補正 死亡率

n.s. はFisherの直接確率検定で有意差がないことを示す。

ゲン葉上で観察された虫数の関係を第 3 困に示した。イ チゴ小葉のナミハダニ黄緑型はイチゴ葉が萎れるに伴 い, 茎を登りインゲン葉へ移動した。放飼前のイチゴ小 葉上の虫数と放飼 24 時間後のインゲン葉上の虫数の間に は正の相関が認められ $\left(\mathrm{y}=0.9228 \mathrm{x}, \quad \mathrm{R}^{2}=0.8503\right)$, 放飼 後24時間で 9 割以上の個体がイチゴ小葉からインゲン葉 上へ移動した。また，24時間後の補正死亡率を簡易接種 後に葉片浸漬した場合と従来どおり小筆を用いて接種し た後に散布法を用いた場合とで比較したところ，いずれ の殺ダニ剂でも両者間には有意差は認められなかった (Fisher の直接確率検定，危険率 1\%，第 4 図)。

\section{考察}

奈良県の促成イチゴ栽培で主に使用されている殺ダニ 剂は, ビフェナゼート水和剂, ミルベメクチン水和剂, エマメクチン安息香酸塩乳剂，シエノピラフェン水和剂 と気門封鎖剤である。このうちシエノピラフェン水和剤, シフルメトフェン水和剂は福岡県（柳田ら，2013）, 三 重県（大仲・西野，2013）, 愛知県（石川・江口，2014）
から，ビフェナゼート水和剂も福岡県（柳田ら，2013） から感受性の低下が報告されている。ミルベメクチン水 和剂についても効果低下の報告（大仲・西野, 2013 ; 柳 田ら, 2013 ; 石川・江口, 2014）があることから, 実際 の防除においていずれの薬剂を選択すべきか, 栽培者は もとより普及指導員等の現場指導者でも判断するのは難 しい状況となっている。このため, 迅速で栽培現場での 薬剂使用状況に対応した結果が得られる感受性検定法が 求められている。

今回の結果から, あらかじめ殺ダ二剂に葉片を浸漬す る方法では, エマメクチン安息香酸塩乳剤において, 補 正死亡率が散布法よりも低くなることが明らかとなっ た。生産者への防除指導でもハダ二類に直接薬液が付着 するように散布することを指導している。このため, 現 在利用されている殺ダ二剂の検定には直接薬液に接触す る方法が望ましいと考えられた。ただし, 散布法には回 転式散布塔などの散布器具が必要となるが, これを装備 していない病害虫防除所等もある。しかも, 回転式散布 塔は既に販売が中止されており, 入手することは難しい。 今回はこれに代わる簡便な散布器具を使用した。今後は, この散布器具の散布粒子径やそのばらつき等を調べ, 回 転式散布塔の代替品としての性能を明らかにする必要が ある。

次に, 今回開発した小筆を用いない接種法は, イチゴ 小葉に寄生するハダニ数からインゲン葉に移動するハダ 二数が概ね予想できる。このため, 検定に必要な頭数を イチゴ小葉に寄生するハダ二数で調整することが可能と 考えられる。移動に要する時間が 1 日程度かかるものの, 放置しておくだけであり，簡易な方法として利用できる と考えられる。簡易な検定法としては採集してきた葉を 直接薬液に浸漬する方法（高梨ら，2009）が知られてい る。しかし, 栽培現場から採集してきた葉には死亡個体 や移動中に損傷した個体なども含まれている。このため, 浸漬前に十分な観察が必要となる。一方, 今回の方法で はインゲン葉に移動させるので元気な生存虫のみを対象 にできる。

また， 1 例だけであるが，ハダニの簡易接種後のイン ゲン葉を直接薬液に浸漬する方法でも, 小筆を用いて接 種後に散布法を用いた場合と同様の結果を得ることがで きた。今後より多くの事例を集める必要はあるが, 簡易 検定法として利用できる可能性は高い。

今回の実験では寄主植物のイチゴではなく, インゲン を用いた。ナミハダニ黄緑型は寄主植物の範囲が広いた め, 感受性検定にはどのような作物に寄生していた場合 でもインゲンを䬣植物とすれば飼育できる。また，イン 
ゲンは栽培が容易で生育が速いことから，ナミハダニの 飼育に広く用いられてきた（真梶，1980）。ただし，い つでも感受性検定が実施できるようにするためにはイン ゲンを常に栽培しておく必要がある。この維持管理には 相当の時間を要することから，今後は Kwon らが開発し たガラス管を用いる方法（Kwon et al., 2010）などを参 考に，植物体を利用しない検定法の開発が必要である。

摘 要
ビフェナゼート水和剤, エマメクチン安息香酸塩乳剤,
シエノピラフェン水和剤を用いてインゲン葉片に接種し たハダニに殺ダ二剂を散布する方法（散布法）とあらか じめ殺ダニ剂に浸漬したインゲン葉片に八ダニを接種す る方法（浸漬法）の補正死亡率をイチゴに寄生するナミ 八ダニ黄緑型で比較した。ビフェナゼート水和剤とシエ ノピラフェン水和剤では両者の間に差はなかったが，エ マメクチン安息香酸塩乳剂では散布法より浸漬法での補 正死亡率が有意に低くなった。

また，小筆を用いない八ダニ接種法として，初生葉が 展開したインゲン茎水挿しの茎元にイチゴ小葉を置き,
1 日程度放置することで，イチゴ小葉に寄生するハダニ のほとんどがインゲン葉へ移動した。これを殺ダニ剤に 浸漬することで散布法と同様の補正死亡率が得られた。

\section{引用文献}

Abbot, W. S. (1925) J. Econ. Entomol. 18: 265-267.

浜村徹三（1996）植物ダ二学. 全国農村教育協会, 東京, pp. 323-330.

石川博司・江口敏弥（2014）関西病虫研報 56 : 139-143.

國本佳範（2010）奈良農総研七研報 $41: 23-28$.

Kwon, D. H., D. Y. Song, S. Kang, J. J. Ahn, J-H. Lee, B. R. Choi, S. W. Lee, J-H. Kim and S. H. Lee (2010) J. Asia Pac. Entomol. 13: 333-337.

望月雅俊 (1998) 植物防疫 $52:$ 96-98.

大仲桂太・西野 実 (2013) 関西病虫研報 $55: 113-115$.

真梶徳純（1970）植物防疫 $24: 455-460$.

真梶徳純 (1980) 昆虫実験法. 材料・実習編. 学会出版センター, 東京, pp. 80-83.

高梨祐明・土師 岳・足立嘉彦・豊島真吾 (2009) 東北農研研 報 $110: 177-186$.

柳田裕紹・森田茂樹 - 國丸謙二 (2013) 福岡農総試研究報告 $32: 33-36$. 